\title{
The Influences of Reward Justice and Task Oriented Leadership Style toward Perceived Organizational Support
}

\author{
Mauli Elayati ${ }^{1}$, Siti Nuzulia ${ }^{2 *}$
}

\section{ABSTRACT}

Company always has to pay attention to the employee's well being by giving organization support to their employees. Organization supports from the company will be perceived by the employee as general confidence of organization awareness to their well being. Less perceived organizational support for employee will lead to less working spirit and will make it harder to achieve maximum results. Some of the factors that could affect perceived organizational support for employees are reward justice and task oriented leadership behavior.

This study tried to assess three hypotheses. The first hypothesis is there is a relationship between reward justice and task oriented leadership style toward perceived organizational support. The second hypothesis is there is a relationship between reward justice toward organizational support, and the third hypothesis is there is a relationship between task oriented leadership styles toward perceived organizational support.

The results showed that simultaneously reward justice and task oriented leadership style together significantly affect perceived organizational support, so the hypothesis is confirmed. The coefficient value ( $\mathrm{R}$ Square) is 0.433 . This means that contribution of reward justice and task oriented leadership style toward perceived organizational support is $43.3 \%$. The second hypothesis is also confirmed. While the coefficient value of regression line variable equation of task oriented leadership style to perceived organizational support is -0.346 . This means that, partially there is no significant negative impact between tasks oriented leadership style and perceived organizational support. The implication of this research result is that the involvement of officials and salaries is needed more and influential for employee, compared with the presence of the leader.

Keywords: Reward Justice, Task Oriented Leadership Style, Perceived Organizational Support.

\footnotetext{
${ }^{1}$ Department of Psychology, Faculty of Education, Semarang State University. Gedung A1. 2nd Floor Jl. Raya Sekaran Gunungpati, Semarang, Jawa Tengah, Indonesia

${ }^{2}$ Department of Psychology, Faculty of Education, Semarang State University. Gedung A1. 2nd Floor Jl. Raya Sekaran Gunungpati, Semarang, Jawa Tengah, Indonesia

*Responding Author

(C) 2016 I M Elayati, S Nuzulia; licensee IJIP. This is an Open Access Research distributed under the terms of the Creative Commons Attribution License (http://creativecommons.org/licenses/by/2.0), which permits unrestricted use, distribution, and reproduction in any Medium, provided the original work is properly cited.
} 


\section{The Influences of Reward Justice and Task Oriented Leadership Style Toward Perceived Organizational Support}

Perceived organizational support is a global conviction formed by employees concerning their assessments to organization that formed based on their experience regarding their organization policy and procedure, interaction with organization agents and perception concerning organization caring to their prosperty (Rhoades \& Eisenberger, 2002).

Rhoades and Eisenberger (2002) suggest their statement based on the meta-analysis research result that the organizational support perception dimension enclose fair organizational procedures that overflow organization policy and manner of treatment equity, supervisor support or the leader support, favorable rewards and job conditions that overflow: recognition, pay, promotions, job security, job autonomy and work procedures, job-related stressors, work overload and training for the employees. Furthermore organization is an important source for their socio-emotional needs like respect, caring, and tangible benefit as salary and health allowance.

One of organization supports that can improve the perceived organizational support is benefit presenting factor regarding the work ability. The equity in reward presenting is a thing that must be noticed by the company to the employees. It is about "is the reward that they get have adequate?" or "What the employess have done?. Noe et al. (2011) called it as the equity of rewards that is defined as the assessment which is made by people about the rewards that they got comparing the others got as their reference.

The used aspects to measure the equity of repayment by theory using is suggested by Mathis \& Jackson (2002) that the aspects from the rewards equity are internal equity, external equity, and the openness of salary. Rhoades et al., (2001) said that rewards will increase perceived organizational support and organizational rewards connect positively with perceived organizational support. Ardianto (2009) shows that there is positive effect between organizational rewards regarding perceived organizational support.

The balance between employees work ability and their rewards show equity of rewards that they got from the company. It brings about the employees assessor regarding the reward they get is fair and agreeable with the work that they have done and notices their needs thus the employees will assess from the accepted reward justice as on of company support forms regarding the employees in the company very positive.

As fair as the employees reward get from the company, thus they will assess that the support from the company to them is good exceedingly or in other word is positive perceived organizational support. On the contrary, as unfair as their reward, thus they will assess the company support to them is not enough or in other word is negative perceived organizational support.

Besides the support that having character of repayment regarding a job in a company, an employee need exceedingly a leadership which can bring the company to its aim. Yukl said 


\section{The Influences of Reward Justice and Task Oriented Leadership Style Toward Perceived Organizational Support}

(2009), a leadership style that have a high attention to the employees can regard as a positive thing by them and also as a positive support that they get from the company to them.

The using of leadershhip style that orientate to the task is assumed that it will affect to the employees assessment regarding perceived organizational support. This leadership style is more consider the production which tending to emphasize technically aspects and job task where the employees is seen as equipments to reach the company aim so that it ignore the employees prosperty thus it will form a low perceived organizational support for the employees.

According to Bangun (2012), the leadership styles are employees oriented leadership style and task oriented leadership style. On a research on Ohio state, Muchlas (2008) explain that the task oriented leadership style in this study is called initiating structure. It organize the duty of jobs to reach the company aim by giving special tasks to the employees, hoping the employees hold the fixed work standard, and emphasize the important of the meeting time limit. The leader that use this leadership in high level is tending to increase the complaints, work absent, work resign, and low satisfaction level of the employees who do the routine tasks. According to Ivancevich et al., (2006), the leader have to set the relationship in the group, tending to make a mutual pattern in distribution of communication, and set how an task which leader do with high initiation structure tendention is having focus on target and result. This leadership is seen less to pay attention to the existension and hard work of the employees so that can affect on the employees assessments regarding the company support is very low.

The above explanation is regarding the task oriented leadership style where a leader just notices the target achieving from the company. Besides, employees hard work and existence from the company is less of attention thus the employees will assess that the company support for them is very low or in other word is negative perceived organizational support. On the contrary, if the employees assess that this leadership style is less using by the leader where the leader quite notice the employees hard work and existence, the employees will assess that the company support for them is quite good or in other word is positive perceived organizational support.

According to the explanation above regarding perceived organizational support, it is important to do research about perceived organizational support. It assumed that reward justice and task oriented leadership style have effect to perceived organizational support. If the employees assess that the company give them fair reward so the value of perceived organizational support is positive and if the task oriented leadership style is more applied, then the value of perceived organizational support is negative.

\section{RESEARCH METHODOLOGY}

This research is quantitative research with variety of correlation. The characteristic of the sample are the employees, the minimum education level is high school or being equal, minimum work experience is one year. Total respondents for this research are 49 respondents. The variables of 


\section{The Influences of Reward Justice and Task Oriented Leadership Style Toward Perceived Organizational Support}

this research are reward justice and task oriented leadership style that as independent variable and perceived organizational support as dependent variable.

This research use psychology scale as data collecting method which are perceived organizational support scale, reward justice scale, and task oriented leadership style scale. The analysis of validity and reliability use data processor software. The perceived organizational support scale has validity coefficient about 0.291 until 0.700 with reliability coefficient about 0.924 . The reward justice scale has validity coefficient about 0.306 until 0.759 with reliability coefficient about 0.891 . Then, the task oriented leadership style scale has validity coefficient about 0.301 until 0.658 with reliability coefficient about 0.860 .

\section{RESEARCH RESULT}

Assumption Test Result

Normality Test. The result of normality test on perceived organizational support scale is gained by use One-Sample Kolmogorov-Smirnov technique. From the test, it is gained K-S Z coefficient is about 0.569 with significant value is about 0,903 then $\mathrm{p}$ (error) $>0.05$ or $0.903>$ 0.05 . This shows the data distribution on perceived organizational support scale that has value as normal distribution. On the rearward justice scale, it is gained K-S Z coefficient is about 0.691 with significant value is about 0.726 then $p>0.05$ or $0.726>0.05$. This shows that data distribution on reward justice scale is normal. The task oriented leadership style scale has K-S Z coefficient is about 1,269 with significant values about 0.080 then $p>0.05$ or $0.080>0.05$. This result shows that the data distribution of the task oriented leadership style scale is normal.

Linearity Test. The linearity test result between perceived organizational support with reward justice shows that the value of $F$ is about 33.327 with 0.000 significantly then $p<0.05$ at $0,000<$ 0,05 . The result shows that on the relationship of perceived organizational support variable regarding reward justice is linear. Whereas, the perceived organizational support linearity test result with task oriented leadership style is gained $\mathrm{F}$ that is about 1.030 with significantly about 0.318 then $\mathrm{p}>0.05$ or $0.318>0.05$. the result shows that on the relationship of perceived organizational support variable regarding task oriented leadership style is not linear.

Multicolinearity Test. The multicolinearity test result shows that tolerance value of reward justice variable and task leadership style is about 0.839 that means it is bigger than 0.1 and VIF about 1.191 is smaller than 10 thus it can be stated that it has no multicolinearity problem in this research model.

Heteroskedasticity Test. Heterokedasticity test result shows that all of the independent variables have value as sig $\geq 0.05$. Thus, there are no independent variables which statistics significantly affects the dependent variables Res_2. This is observed from the sig value on each of all independent variables is 0.05 . Thus, it can be concluded that regression model does not contain any heterokedacity. 


\section{The Influences of Reward Justice and Task Oriented Leadership Style Toward Perceived Organizational Support}

\section{Hypothesis Test Result}

The F test is used to knowing about does the independent variables affect significantly regarding the dependent variables simultaneous or jointly, or for knowing about does the regression model can be used to predict the dependent variables or not. The F test result is showed in the Table 1.

Table 1 : Table of F Test Result

ANOVA $^{\text {b }}$

\begin{tabular}{|l|l|r|r|r|r|r|}
\hline Model & Sum of Squares & Df & Mean Square & \multicolumn{1}{|l|}{ F } & \multicolumn{1}{|l|}{ Sig. } \\
\hline 1 & Regression & 4005.539 & 2 & 2002.769 & $\mathbf{1 7 . 5 9 9}$ & $.000^{\mathrm{a}}$ \\
\cline { 2 - 7 } & Residual & 5234.706 & 46 & 113.798 & & \\
\cline { 2 - 7 } & Total & 9240.245 & 48 & & & \\
\hline
\end{tabular}

a. Predictors: (Constant), task oriented leadership style, reward justice

b. Dependent Variable: Perceived Organizational Support

The $\mathrm{F}$ Test result shows that $\mathrm{F}$ value is about 17.599 with significantly level 0.000 . F value calculation $>$ Table of F or $17.599>3.20$ and $\mathrm{p}<0.05$ or $0.000<0.05$. It means that the first hypothesis "the reward justice and task oriented leadership style give effect regarding perceived organizational support is accepted."

The result of determination coefficient test (Table 2) shows the coefficient correlation value (R) is about 0.658 . Whereas, the determination coefficient value ( $R$ Square) is about 0.433 . It means that the reward justice and task oriented leadership style effect contribution regarding perceived organizational support is about $43.3 \%$.

Table 2 : Table of Determination Coefficient Test Result

\begin{tabular}{|l|r|r|r|r|}
\hline Model & R & R Square & Adjusted R Square & \multicolumn{2}{|c|}{$\begin{array}{c}\text { Std. Error of the } \\
\text { Estimate }\end{array}$} \\
\hline 1 & $.658^{\mathrm{a}}$ & .433 & .409 & 10.668 \\
\hline
\end{tabular}

a. Predictors: (Constant), task oriented leadership style, reward justice

Furthermore, it is gained regression line equation $\mathrm{Y}_{\mathrm{c}}=62.089+1.127 \mathrm{X}_{1}-0.346 \mathrm{X}_{2}$.t calculation value for reward justice $\left(\mathrm{X}_{1}\right)$ about 5.815 with significantly level 0.000 . $t$ calculation value $>t$ table or $5.815>2.021$ and $\mathrm{p}<0.05$ at $0.000<0.5$. The result show that there is significant parsially effect between reward justice $\left(\mathrm{X}_{1}\right)$ regarding perceived organizational support $(\mathrm{Y})$. Whereas, t calculation value for task oriented leadership style variable $\left(\mathrm{X}_{2}\right)$ is about -2.254 with significantly level about 0.216 . $\mathrm{T}$ calculation value $<\mathrm{t}$ table or $-2.254<2.021$ and $\mathrm{p}>0.05$. This 
result shows that there is no significant parsially effect between task oriented leadership style variable $\left(\mathrm{X}_{2}\right)$ regarding perceived organizational support $(\mathrm{Y})$.

\section{Table 3 : Table of Multiple Linear Regression Test Result}

\begin{tabular}{|c|c|c|c|c|c|c|}
\hline \multirow{2}{*}{\multicolumn{2}{|c|}{ Model }} & \multicolumn{2}{|c|}{$\begin{array}{c}\text { Unstandardized } \\
\text { Coefficients }\end{array}$} & \multirow{2}{*}{$\begin{array}{c}\text { Standardized } \\
\text { Coefficients }\end{array}$} & \multirow[b]{2}{*}{$\mathbf{t}$} & \multirow[b]{2}{*}{ Sig. } \\
\hline & & B & Std. Error & & & \\
\hline \multirow[t]{3}{*}{1} & (Constant) & 62.089 & 16.788 & & 3.698 & .001 \\
\hline & Reward justice & 1.127 & .194 & .704 & 5.815 & .000 \\
\hline & $\begin{array}{l}\text { Task Oriented } \\
\text { Leadership Style }\end{array}$ & -.346 & .275 & -.152 & -1.254 & .216 \\
\hline
\end{tabular}

Meanwhile, the result of inter-correlation among variables test in this research uses showed in the below table 4 .

Table 4 : Inter-Correlation among Variables Test Result Table Correlations

\begin{tabular}{|c|c|c|c|c|c|c|c|c|c|}
\hline & $\mathrm{X} 1$ & X1.1 & X1.2 & X1.3 & $\mathrm{X} 2$ & X2.1 & X2.2 & X2.3 & $\bar{Y}$ \\
\hline X1 & 1 & $.868^{* *}$ & $.895^{* *}$ & $.766^{* *}$ & $.401^{* *}$ & $.417^{* *}$ & $.317^{*}$ & 220 & $.644^{* *}$ \\
\hline $\mathrm{X} 1.1$ & - & 1 & $.716^{* *}$ & $.473^{* *}$ & ,273 & $.293^{*}$ & ,229 & ,120 & $.662^{* *}$ \\
\hline $\mathrm{X} 1.2$ & - & - & 1 & $.511^{* *}$ & $.453^{* *}$ & $.385^{* *}$ & $.403^{* *}$ & $.310^{*}$ & $.606^{* *}$ \\
\hline X1.3 & - & - & - & 1 & ,274 & $.380^{* *}$ & ,149 & 109 & $.346^{*}$ \\
\hline X2 & - & - & - & - & 1 & $.832^{* *}$ & $.830^{* *}$ & $.779^{* *}$ & ,130 \\
\hline X2.1 & - & - & - & - & - & 1 & $.498^{* *}$ & $.482^{* *}$ & ,093 \\
\hline X2.2 & - & - & - & - & - & - & 1 & $.511^{* *}$ & ,019 \\
\hline $\mathrm{X} 2.3$ & - & - & - & - & - & - & - & 1 & 235 \\
\hline $\mathrm{Y}$ & - & - & - & - & - & - & - & - & 1 \\
\hline
\end{tabular}

${ }^{*} \mathrm{P}>01{ }^{* * \mathrm{P}>05}$, X1:Reward justice, X1.1: Internal Equity, X1.2 : External Equity, X1.3 : Salary Openness. X2: Task Oriented Leadership Style, X2.1: The leader sets and defines the relationship in the group, X2.2: The leader determines and makes his/her role structure and his/her employees' role to reach the formal aim. X2.3: The leader coordinates his/her employees to do their task by using the procedure. Y: Perceived organizational support. 


\section{DISCUSSION}

Perceived organizational support is an organizational support which is assessed globally by the employees concerning as far as where the organization appreciates the contributions, pays attention to the prosperities, listens the complaints, pays attention the life and considers the aim and can be trusted to treat the employees fairly that is formed based on their experience regarding the organization policy and procedure, interacts with organization agents and perceptions concerning the organization caring regarding prosperities.

The reward justice is a fair feeling that employee feel regarding to every his/her income from their company which the amount is fair enough with employee effort and the others income get.

Whereas, the task oriented leadership style is a way, action pattern, or leader behaviour that is oriented to the production slanting directs to the technically aspects to influence other people in order to available to do collaboration work to reach the fixed aims.

The $\mathrm{F}$ test result shows that $\mathrm{F}$ calculation value $>\mathrm{F}$ table or $17.599>3.20$ and the significantly $=$ 0.000. It means the reward justice and task oriented leadership style affects perceived organizational support significantly by means of simultaneous. Thus, the third hypothesis $\left(\mathrm{H}_{3}\right)$ that sounds "the reward justice and task oriented leadership style affects the perceived organizational support" is accepted. The determination coefficient test result shows the correlation coefficient value $(\mathrm{R})$ is about 0.0658 whereas the determination coefficient value $(\mathrm{R}$ Square) is about 0.433 . It means the contribution of reward justice and task oriented leadership style effect regarding perceived organizational support is about $43.3 \%$ while the remainder about $56.7 \%$ is affected or explained by other variables that is not analyzed in this research.

The inter-correlation among variable test result on reward justice variable has significant correlation with perceived organizational support variable with correlation value about 0.644. The regression line equation coefficient value of reward justice variable regarding perceived organizational support is about 1.127 in positive. This shows that the reward justice has relationship that having the same course with perceived organizational support. It means that when each rises of reward justice is a unit then the perceived organizational support will rise about 1.127 with assumption that the other free variables from the regression model is fixed. Besides that, it can be seen on $t$ calculation value of reward justice regarding perceived organizational support ( $\mathrm{t}=5.815$ with $\mathrm{p}=0.000)$. This result shows that there is significant effect between reward justice regarding perceived organizational support by means of partially thus the first hypothesis that sounds "The reward justice gives positive effect to perceived organizational support."

The result of inter-correlation test between perceived organizational support variable with reward justice shows that reward justice variable correlates significantly with perceived organizational support about 0.644. It means the reward justice variable supports the high and low of perceived organizational support variable level. Rhoades dan Eisenberger said (2002 ), perceived 


\section{The Influences of Reward Justice and Task Oriented Leadership Style Toward Perceived Organizational Support}

organizational support is a organizational support that is assessed with full conviction concerning how far the organization assess the contribution, notices the prosperity, listens the complaints, notices the life of employees, considers the aim that has to reach and can be trusted to treat the employees fairly. Fair in this research is illustrated in a reward justice form that is gotten by the employees from the company which is a mutual form the company gives to them according to their effort to the company. The employees have feel the reward giving that the company did will affect positively regarding assess the supports from the company to its employees. This is suitable with the statement of (Rhoades dan Eisenberger, 2002) equity identification, supervisor supports, organization reward and good work condition as organization characteristic affects positively to perceived organizational support.

According to organizational rewards theory, the opportunity to get reward in an assessment is a positive thing from the employees contribution and it have a role to perceived organizational support. Gaeertner and Nollen (Rhoades et al., 2001) said that rewards will increase perceived organizational support and organizational rewards have positive relationship with perceived organizational support. In compliance with Andika Ardianto research (2009), it shows that there is positive effect between organizational rewards regarding perceived organizational support. It indicates that as high as the organizational reward level that is given by the company to its employees, then it will strong then the perceived organizational support level.

With an exchange process, the equity assessment will be easier to do. The exchange can be stated fair if the agreement to give and receive between the two sides is accepted (Faturochman, 2012). The social exchange view point where the work relationship is considered as benefit exchange of tangible and intangible (Hemdi \& Rahim, 2011). Hemdi \& Rahim (2011) argument that the fulfilling of socio-emotional needs that important is quite similar with individual needs fulfilling for respect, awareness, and supports in inter-personal relationship. In the other perspective is the fairness viewpoint in work relationship. In this viewpoint, fairness perspective explains how an individual see the relationship exchange on the hook with fair mutual. (Hemdi \& Rahim, 2011), the exchange theory can explain this research where the perspective to the equity in work relationship is having a connection with fair mutual, in the research concerning "reward justice which is given by the company is affect positively to perceived organizational support." The good reward justice by the employees will give an effect that is having form as mutual regarding positive perceived organizational support for the company.

The coefficient value of task oriented leadership style regression line equation regarding perceived organizational support is about negative 0.346. Besides, it also can be seen on $t$ calculation value of task oriented leadership value variable regarding perceived organizational $\operatorname{support}(\mathrm{t}=-2.254$, significance $=0.216)$. The result shows that there is no significant effect partially between task oriented leadership style value regarding perceived organizational support thus the second hypothesis (H2) that sounds, "The task oriented leadership style has negative effect to perceived organizational support” is declined. 


\section{The Influences of Reward Justice and Task Oriented Leadership Style Toward Perceived Organizational Support}

The inter-correlation test between task oriented leadership style variable with perceived organizational support shows the value is about 0.130 that means it has no significant correlation. The research result shows that the task oriented leadership style has no effect for perceived organizational support meanwhile the leadership style can give effect height or lowness of perceived organizational support if the leader style is equally with reward justice. It is assumed that there is probability to an employee who get the reward which he/she feel is fair enough or suitable with his/her effort will not bring up the way or the leadership style that is applied by the leader of the company.

The task oriented leadership style shows on average criteria about $61 \%$ or it can be said that the leader does not use the task oriented leadership style exceedingly in the work process execution. With the bigger percentage on average criteria, the possibility does not affect exceedingly regarding perceived organizational support. From the descriptive analysis result of perceived organizational support, it is gotten that the percentage is on the same criteria. It is about $65 \%$. That task oriented leadership style and perceived organizational support exist on the same criteria level which make it has no negative effect between the leadership style and perceived organizational support. The high less of task oriented leadership style level that is used by the leader of the company is felt insufficient to can to affect in negative perceived organizational support way.

According to Rhoades \& Eisenberger (2002), for the employees, organization is important source for their socio-emotional needs as like respect, caring, and tangible benefit; salary and health allowance. The possibility on employees will more consider a reward and tangible benefit which is a form of company supports can be seen and felt directly by the employees. Therefore, an task oriented leadership style that is used by the leader to coordinate his/her employees does not affect regarding perceived organizational support that the employees felt where the leadership style has no effect directly or not really important for the employees socio-emotional needs. Gibson, Ivancevich, and Donnelly, (2002) declared on a report from the source figured out that democracy, profit allocation, and information are important things compared with management hierarchy that is position level which is headed by a leader. Moreover, the employees involvements, salary, or earnings is more needed and affect for the employees compared with the leader attendance.

\section{CONCLUSION}

Based on the research and hypothesis test results, the first hypothesis $\left(\mathrm{H}_{1}\right)$ declares that there is positive reward justice effect regarding perceived organizational support. It means that the height of the reward justice has relationship with the perceived organizational support height. The second hypothesis $\left(\mathrm{H}_{2}\right)$ test declares that there is no negative effect of task oriented leadership style to the perceived organizational support. It means that the task oriented leadership style height has no relationship with perceived organizational support height. Last, on third hypothesis $\left(\mathrm{H}_{3}\right)$ test shows that there is effect from reward justice and the task oriented leadership style to 


\section{The Influences of Reward Justice and Task Oriented Leadership Style Toward Perceived Organizational Support}

the perceived organizational support. It means that the reward justice height and the task oriented leadership style lowness give effect to the perceived organizational support effect.

\section{REFERENCES}

Ardianto, Andika. 2009. Perceived Organizational Support sebagai pemediasi pengaruh keadilan prosedural, penghargaan, dan dukungan supervisor terhadap komitmen afektif (Studi pada karyawan PT. POS Indonesia (Persero) Kantor POS Surakarta.

Bangun, Wilson. 2012. Manajemen Sumber Daya Manusia. Jakarta: Erlangga.

Eisenberger, R., Cummings, J., Armeli, S., \& Lynch, P. 1990. "Perceived organizational support and employee diligence, commitment, and innovation”. Journal of Applied Psychology,75: 51-59.

Faturochman. 2012. Keadilan Perespektif Psikologi. Yogyakarta: Pustaka Pelajar

Gibson, Ivancevich, \& Donnelly. 2002. Organisasi Jilid 2. Tangerang: Binapura Aksara.

Hemdi, M., \& Rahim, A. 2011. The Effect of Psychological Contract and Affective Commitment on Turnover Intentions of Hotel Managers Faculty of Business Management. International Journal of Businessand Social Science, 2, 76-89.

Ivancevich, John M, Robert Konopaske \& Michael T. Matteson. 2006. Perilaku dan Manajemen Organisasi Jilid 2. Jakarta: Erlangga.

Mathis, Robert L \& Jhon H. Jackson. 2002. Manajemen Sumberdaya Manusia. Jakarta: Salemba Empat.

Noe, R.A., Hollenbeck, J.R., Gerhart, B., \& Wright, P.M. 2011. Manajemen Sumber Daya Manusia: Mencapai Keunggulan Bersaing, Edisi 6. Penerbit Salemba Empat.

Rhoades, L., Eisenberger, R., \& Armeli, S. 2001. Affective commitment to the organization: The contribution of perceived organizational support. Journal of Applied Psychology, 86, 825-836

Rhoades, Linda dan Robert Eisenberger. 2002. "Perceived Organizational Support: A Review of the Literature”. Journal of Applied Psychology. Vol 87. No 4: 698-714.

Wayne, S.J., Shore, L.M.., \& Liden, R.C. 2002. "The Role of Fair Treatment and Rewards in Perceptions of Organizational Support and Leader-Member Exchange”. Journal of Management Journal, 87: 590-598.

Yukl, Gary. 2009. Kepemimpinan Dalam Organisasi Edisi kelima. Jakarta: PT Indeks.

How to cite this article: M Elayati, S Nuzulia (2016), The Influences of Reward Justice and Task Oriented Leadership Style Toward Perceived Organizational Support, International Journal of Indian Psychology, Volume 3, Issue 3, No. 7, DIP: 18.01.126/20160303, ISBN: 978-1-365$12175-3$ 